\title{
STEM Education-Career Pathway for Emerging Forensic Analytics: Innovative Professional Development in Multimodal Environments
}

\author{
Joselina Cheng \\ University of Central Oklahoma \\ Michael Ho-Chang Chae \\ University of Central Oklahoma \\ Rebekah Feng \\ Becks Intelligence Group
}

This multi-tier STEM Career Builder grant, funded by the National Science Foundation, focused on professional development to prepare high school teachers for teaching information systems and analytics. The project teams partnered with Apple, IBM, and the FBI to research and develop innovations including forensic databases, immersive environments, and forensic analytical tools with interdisciplinary curricula, real-world contexts, and emerging technologies. Thirty teachers were provided with four knowledgeacquisition and skill-development venues with innovations: an annual conference, teacher institute, and a summer academy. Mixed data were collected via surveys and focus groups. Project findings revealed that strategic PD and innovations impacted teachers positively.

Keywords: partnership, equity-skill gap, professional development, forensic analytics, machine learning

\section{INTRODUCTION \& CONTEXTUAL BACKGROUND}

\section{Gender-Equity \& Skill Gaps}

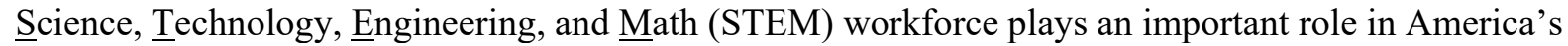
innovative capacity and global competitiveness (US Census Bureau, n.d.). While women made gains - from $8 \%$ of STEM workers in 1970 to $27 \%$ in 2019 , while men made up $73 \%$ of all STEM workers (US Census Bureau, n.d.). Without access to equitable opportunities for career exploration, knowledge acquisition of interdisciplinary contents, and development of the $21^{\text {st }}$ century skills can further impede women's abilities to participate in the highly competitive global workforce and succeed in fast-growing professions (e.g. data science and analytics). To address the gender-equity and skill gaps, the University of Central Oklahoma (UCO) proposed a three-year STEM CareerBuilder project with innovative interventions to support women during different phases of their STEM education-career pathway. The proposal was submitted to the National Science Foundation (NSF) in the fall of 2017. 


\section{Alignment With NSF Priorities \& Funding for the R\&D of Innovative Interventions}

The proposed STEM Career Builder project was funded by NSF for the research and development (R\&D) of teaching and learning innovations under their Innovative Technology Experiences for Students and Teachers (ITEST) program (award \#1758975) for the 2018-2022 periods. The STEM Career Builder aligned with the priorities of NSF to build the capacity of human capital with a diverse, equitable, and innovative STEM workforce to grow human capital, sustain U.S. long-term competitiveness, and secure global leadership (NSF, 2019). To address educational needs and align with NSF priorities, the STEM Career Builder project team collaborated with Government-Industry-University (GIU) partners to leverage business and industry partners, conduct the research and development (R\&D), and implement the following multi-tier interventions to support women at different phases of their STEM education-career pursuit. These multi-tier interventions are designed with the lens of forensics to strategically provide women with equitable access to career-exploration, knowledge-acquisition, and skill-development venues, so that women can be better prepared for emerging careers (e.g. analytics, data science).
(1) Teacher professional development (PD)
(4) Mentoring
(2) Computer Forensics Summer Academy
(5) Internships
(3) Job shadowing
(6) Research fellowships

These multi-tier interventions were supported with innovative teaching and learning tools with interdisciplinary STEM contents, real-world contexts, and emerging technologies to harness the data revolution (NSF, 2019). Further, NSF invests in innovative projects to study and improve innovations to better prepare K-12 teachers with "technology-rich experiences" so that teachers could better engage their students in authentic environments and to increase socio-emotional (e.g. career awareness and interests) and cognitive outcomes (e.g. STEM content knowledge and analytical skills), which are crucial for our youth to participate in the highly competitive global workforce.

\section{Rationale, Scope, \& Components of Teacher Development}

Oklahoma does not have a technology plan and state budget for professional development (PD). To address professional needs, this paper focused on the first intervention, teacher PD so that our youth are better prepared for the future workforce. Four PD components are: (1) Transformative Learning Conference; (2) Teacher institute; (3) Computer Forensics Summer Academy; and (4) on-going support for teachers to incorporate what's learned into their classrooms.

\section{Synergized Partnerships}

To help teachers stay current with technological trends and develop STEM-related curricula with realworld contexts, the project team formed partnerships with government, industry, and university (GIU) at the city (Edmond), state (the Oklahoma State Bureau of Investigation), federal (the FBI), and international levels (e.g. Apple, IBM). Alliances with non-profit organizations and women-own businesses include the National Center for Women \& Information Technology, Oklahoma Women in Technology, MN Associates, and Inciter, LLC. The project team leveraged partners' technological infrastructures and human resources to design and implement components of teacher PD.

\section{Lenses for the R\&D of Teacher-PD Components}

Forensics is used primarily as a lens through which learners examine STEM and Information Systems (IS) discipline content more broadly. The application of new skills and understandings, to solve modernday crimes in real-world scenarios, using innovative technologies in authentic ways, serves as thematic context for the generalizable STEM, IS, and workforce development.

\section{Project Goal \& Program Objectives for Addressing Gender-Skill Gaps}

The overachieving goal of the STEM Career Builder project was to discover what partnerships and interventions can effectively interest, motivate, and support women to pursue education-career paths within STEM. With a focus on teacher PD and efforts to motivate the STEP participation by the underserved 
population, venues for recruiting female high school teachers included: The Science newsletter, \#OKScience Facebook group, Oklahoma ESPCoR Women in Science Conference, and underperforming schools in the Central Oklahoma Regional STEM Alliance (COSTEMA). COSTEMA is an initiative designed to identify the underserved in STEM education by encouraging partnership between industry, educational institutions, and the community. To address the skill gap, the R\&D of strategic teacher PD and innovative tools would be implemented to enhance teachers prepared for promoting and teaching STEMrelated information systems with analytical technologies.

\section{Research Questions}

This study sought to explore the effects of innovative teacher PD strategies on teacher socio-emotional and cognitive outcomes to form the basis for answering research questions below:

1. To what degree does the TL Conference affect teacher career awareness?

2. To what degree does the Teacher Institute affect teacher content knowledge?

3. To what degree does the CF Summer Academy affect teacher intention to incorporate learned contents, information systems (IS), and analytics into their STEM classrooms?

\section{EMERGING CAREERS AND THE R\&D OF FORENSIC ANALYTICS TOOLKIT}

The project team hypothesized, to better educate our youth; teachers must first be better prepared professionally. This section is organized with discussions of an integrated workforce model which formed the foundation for the design and the development of strategic teacher PD and innovative intellectual properties (e.g., immersive environments and simulated databases, and analytical tools). These innovations would be used to enhance teacher preparedness for promoting and teaching STEM-related courses with information systems and analytical tools.

\section{An Integrated Workforce-Development Model for Emerging Careers}

For the teacher PD, a NSF workforce framework was adopted to form the foundation for integrating three emerging careers: (1) computer forensics, (2) analytics, and (3) forensic analytics. These convergent fields, which have interdisciplinary nature, are data-centric. They were used as lenses through which participants examined STEM and information systems (IS) disciplinary contents more broadly. The application of new skills and understandings, to solve modern-day crimes in real-world scenarios, using innovative technologies in authentic ways, serves as thematic context for the generalizable STEM, IS, and workforce development. Sub sections describe the applicability to other disciplines and transferability of analytical skills into domains of emerging careers.

\section{Computer Forensics (CF)}

$\mathrm{CF}$, which is a subfield of forensics, enables investigators to use a variety of technology tools to analyze and preserve evidence from compromised networks or computers (Koroniotis, Moustafa, Sitnikova, \& Turnbull, 2019; U.S. Department of Defense United States Cyber Command, n.d.). The need for CF professionals is becoming a national priority due to increased reliance on emerging technologies to solve modern-day crimes including security breaches, hacking, cybercrime, white-collar scandals, identity theft, and terrorism (Catelli, 2016; U.S. Department of Defense United States Cyber Command, n.d.). Solving modern-day cybercrimes requires specialized learning, including knowledge and practices from STEM discipline areas as well as competencies with technology and soft skills valued by employers (e.g., analytical thinking). According to the US Bureau of Labor of Statistics, the rate of employment growth for CF professionals will be much faster than average through 2024 - at $27 \%$ nationally and $31 \%$ in Oklahoma (Oklahoma Employment Security Commission, n.d.; US Bureau of Labor Statistics, n.d.; Women in computer science, n.d.). Despite the rising demands in the emerging CF profession, Oklahoma does not have a technology plan with dedicated funding and infrastructure to support STEM professional development to teach computer forensics courses in cutting-edge labs. Thus, there are limited computer forensics courses targeted to high school students. Only one elective and half-unit (semester long) course, 
Computer and Cyber Security, is offered in a dozen out of 425 high schools in Oklahoma, due to the lack of unqualified K-12 educators to each computer forensics in a modern-day forensic lab (Carayannis, Alexander, \& Ioannidis, 2000; Support K-12 Computer Science Education in Oklahoma, n.d.; Oklahoma State Regents of higher education, n.d.).

Analytics

According to Mortenson, Doherty, and Robinson (2015), analytics evolved from the periods of (1) quantitative methods (e.g. math and statistics), (2) decision science (e.g. forensics and criminal justice), and (3) technologies (e.g. computer science, information system (See Figure 1). Within the context of this paper, teachers would learn analytical tools were used to solve modern-day crimes. Teachers also learned how to help their students understand how to apply analytics to other disciplines; and transfer analytical skills into the domains of emerging careers (e.g. AI and machine learning).

\section{FIGURE 1 AN INTEGRATED MODEL FOR CONVERGENT CAREERS}

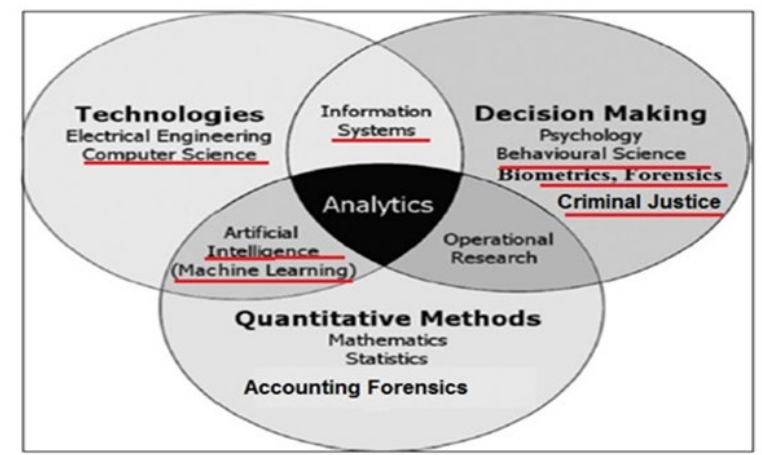

(Adapted from Mortenson, et al., 2015)

Forensics Analytics

Conventionally, forensic data analysis, a branch of Computer Forensics, aims to examine structured data (e.g. numbers and characters) with regard to incidents of white-collar crimes (Bănărescu, 2015; Department of Defense United States Cyber Command, n.d.). Investigators often analyze financial data and identify patterns of fraudulent activities through the sources of IS and databases (Shalaginov \& Franke, 2017). Specifically, forensics analytics, in the context of this paper, is an integration of computer and data science with a focus on innovative teaching and learning tools developed by project team. These innovations were designed to address the growing need for CF professionals as the result of increased reliance on emerging technology (e.g. AI and machine learning), recognition of the costs, and difficulty of dealing with modern-day crimes (Jofre \& Gerlach, 2018; Saini \& Kapoor, 2016). Forensic professionals and law-enforcement agents (e.g. an FBI agent) would demonstrate how to comb through different types of criminal data (e.g. biometrics, DNA), identify patterns, and solve sophisticated crimes.

\section{Integrating Information System (IS) With Innovative Forensic Analytics Toolkits}

The costs of solving these complex crimes continue to rise as crime-solving often requires sophisticated technological infrastructures and innovative tools to safeguard the network without comprising the functions and privacy of private or sensitive information (Choo, 2008; U.S. Department of Defense United States Cyber Command, n.d.). According to Morgan (2019), the cost of cybercrime is anticipated to double and grow to $\$ 6$ trillion by 2021 . To ensure teachers have access to these forensic-analytics tools, the project team partnered with GIU institutions to leverage the existing technological infrastructures, resources, and expertise to simulate innovative teaching and learning analytical tools. 
The skills and knowledge required to effectively use IS tools, first within then eventually beyond the context of forensic investigation activities, make up a large portion of the program's outcomes. Participants learn them in a fashion that integrates IS fully with the other STEM- and workforce-related outcomes anticipated: They apply their growing IS skillset to learn other content even as that content (e.g., analytic thinking skills) serves as the vehicle to increase proficiency with IS tools. Program activities further this approach by providing women with collaborative career and skill-building explorations utilizing common workplace technologies across multiple IS realms - databases, programming, and analytics -in truly integrated ways. Sections below are discussion of innovations including forensics and biometrics information systems (IS) and human-computer simulations.

\section{Criminal Databases and Information Systems}

High school girls in an out-of-school STEM learning program cannot be granted access to compare actual crime scene samples to profiles in live, law-enforcement databases. Thus, a senior forensic professional who represented one of the GIU partners, the Oklahoma State Bureau of Investigation (OSBI) helped the project team develop online simulations that mimic three criminal databases: cold cases, Combined DNA Index System (CODIS), and Automated Fingerprint Identification System (AFIS).

\section{Cold-Case Information System}

The project team used Microsoft Access to model how multiple datasets (e.g. Case, Victim, and the Officer) were joined with primary and foreign keys to demonstrate the entity relations (See Figure 2). To model data relations, $\underline{\text { Structured }}$ Query Language (SQL) was used to retrieve criminal data from multiple tables by joining tables using primary and foreign keys. The query was used to generate criminal incident reports and cold cases.

\section{FIGURE 2}

\section{ENTITY RELATIONSHIP DIAGRAM WITH CRIMINAL DATABASES}

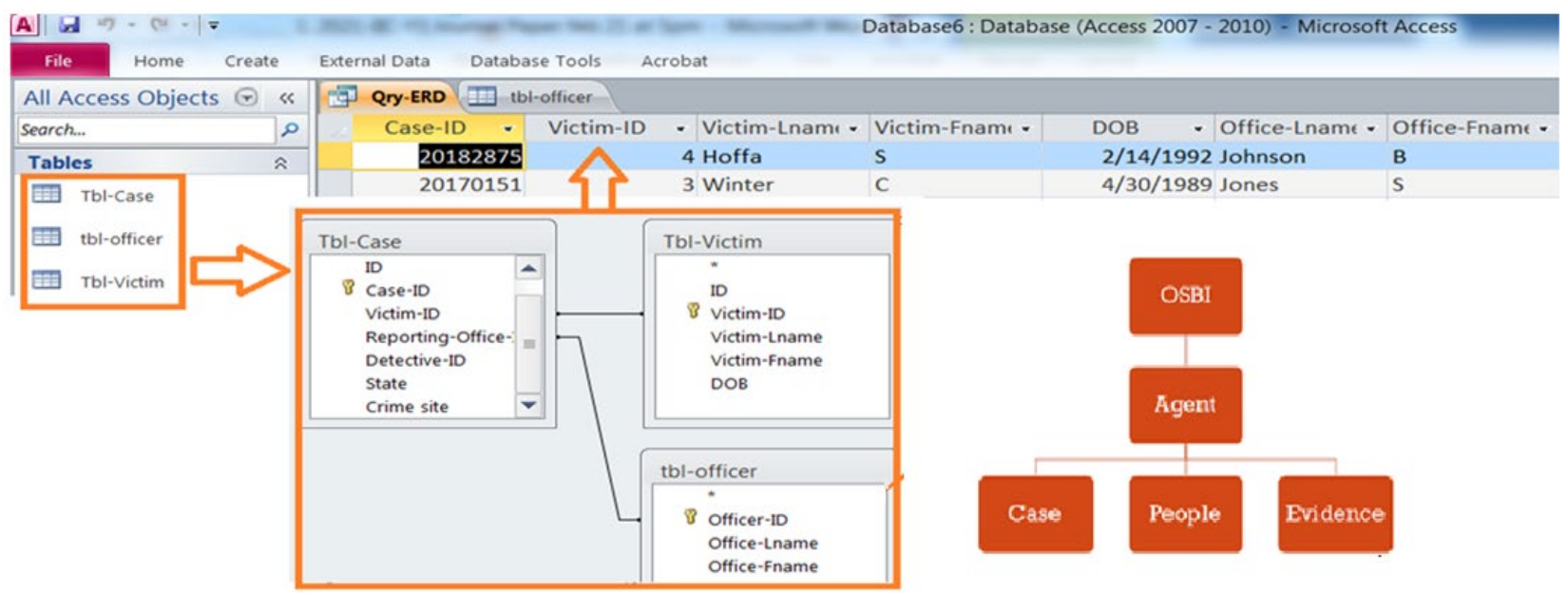

AFIS. The FBI created this database information system to store biometrics (e.g. fingerprints). To mimic AFIS, the OSBI agent helped the project team simulate an AFIS (SIM-AFIS) databases and a search engine as a forensic analytical tools. This tool would be used by participants to search for a matched perpetrator's fingerprint of a suspect. To train the computer machine, the fingerprint images were generated using a Synthetic Fingerprint Generator program (Biometric System Laboratory, n.d.). Generated images use directional map generation, density map generation, ridge pattern generation, noising, and rendering to create realistic prints (Shalaginov \& Franke, 2017). The overall application was built using the Unity game engine, written in $\mathrm{C \#}$, and deployed as a web application for all modern browsers. 
CODIS \& Secured Forensic Data Sharing via Blockchain. The FBI created this database information system to store DNA profiles for crime solving. Since high school teachers were not given access to the real CODIS, the project team collaborated with an OSBI agent to simulate CODIS (SIM-CODIS) using blockchain technology to conceptualize a software system named, BioShare, for forensic scientists and law enforcement agents to transfer and share digital evidence securely. This hybrid-data transfer is a private service, which is immutable, secure, and trackable, provides a rich interface to visualize an encrypted file transfer. Each transfer stores metadata (sender's address, receiver's address, the file's hash, and a timestamp) in a ledger to track and verify the data. The core technologies used for this project are HTML, CSS, and Javascript.

\section{TEACHER-PD VENUS WITH IMMERSIVE ENVIRONMENTS \& FORENSIC ANALYTICS}

This section describes four teacher-PD components: Transformative Learning conference, Teacher Institute, Computer Forensics (CF) Summer Academy, and on-going support for teachers to incorporate the forensic-analytics (FA) toolkit to teach IS with analytics. These PD components were designed to better prepare high school teachers with strategic pedagogy (e.g. problem-, inquiry-based learning), STEMForensic contents, and real-world context. As stated in prior sections, teachers are hypothesized to play an important role for broadening the STEM participation by female high school girls. Thus, training teachers on STEM-related careers is seen as an important part of the project, by increasing teachers' fundamental knowledge in the STEM-related field. The delivery methods ("modalities") are: face-to-face in 2018, hybrid in 2019, and virtual in 2020 due to the pandemic.

\section{Transformative Learning (TL) Conference}

The conference was a one-day event. The main objective of the TL Conference was to promote innovative pedagogies with real-world contexts to transform education. These pedagogical approaches were incorporated to refine the interventions to promote STEM participation and enhance experiential learning experiences. STEM professionals who represented GIU partners presented topics, including trends and skill sets to succeed in emerging careers. While the annual Transformative Learning Conference was cancelled, teacher participants were provided with online trainings on strategic pedagogies (e.g. inquiry-based, project-based, and problem-based) to promote active learning. Further, STEM professionals also shared how to succeed in these professions with required interdisciplinary (e.g. STEM) knowledge, analytical skills, and technical abilities (KSA).

\section{Teacher Institute}

The institute was two-day event to occur in the spring semester. Day one was a webinar with Crime Scene Investigation (CSI) modules for teachers to complete. Going thru the same CSI modules prepared teachers to help students. Teachers received a certificate upon completion and it could be counted towards in-service credit. Day two was a Teacher Orientation (dry run) one day prior to the summer academy. The main objective of the institute was to increase teacher content knowledge. Going thru the academy agenda also prepared teachers to facilitate the crime-solving activities.

\section{Computer Forensics (CF) Summer Academy}

The CF Summer Academy was attended in person in 2018, hybrid in 2019, and virtual in 2020 due to the COVID-19 pandemic (See Appendix A for the agenda). While technologies played a part in prior years, information communication technology (ICT) was critical for the successful implementation of year-three CF Summer Academy. All collaborative digital platforms and innovative tools were supported by ICT to host year-three academy. High school teacher and girl participants attended professional presentations via Zoom, access content modules and materials via the learning management platform (D2L), and collaborated team projects via Zooms' breakout sessions, and used a mobile app, GroupMe, for daily check-in and texting group-related information. 
Teacher Roles

When teachers and students lived on UCO campus in 2018 and 2019, teachers would conduct team briefing and facilitated the crime-solving process (See Figure 3). For 2020, teachers would conduct the team briefing via Zoom's breakout sessions.

\section{FIGURE 3 \\ CRIME-SOLVING DIAGRAM}

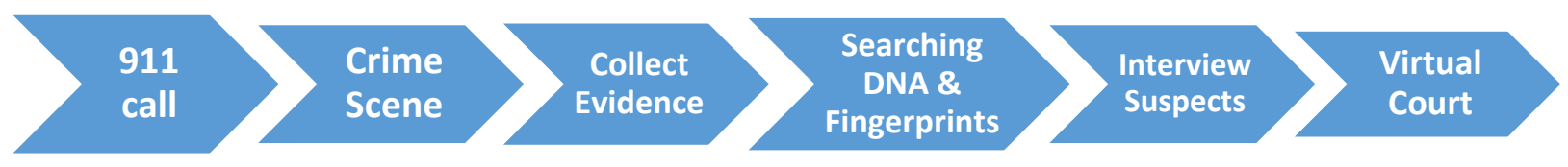

\section{Storyboard of Four Cold Cases}

An OSBI agent presented an overview of four cold cases (See Table 1). The storyboard of these cold cases was based on real-world scenarios about a criminal who stalked his victims, burglarized' their houses, stole computers, hacked into a network to access personal information, and used it for attempted blackmail to lure in victims. Digital evidence for these cold cases included partial fingerprints and blood on the victim's cloth recovered from several crime scenes (See Appendix B for the excerpt of cold cases).

TABLE 1

FOUR COLD CASES DESIGNED TO DEVELOP LEARNERS'ANALYTICAL SKILLS

\begin{tabular}{c|l|c|c|c|c}
\hline Victim & \multicolumn{1}{|c|}{$\begin{array}{c}\text { Cold Case \# (descending } \\
\text { order) }\end{array}$} & $\begin{array}{c}\text { Report } \\
\text { Date }\end{array}$ & $\begin{array}{c}\text { Reporting } \\
\text { Officer }\end{array}$ & Detective & $\begin{array}{c}\text { College } \\
\text { Campus }\end{array}$ \\
\hline Williams, & $\begin{array}{l}2015-1789 \text { (Stalking report) } \\
\text { Jessica }\end{array}$ & $\begin{array}{l}10 / 18 / 2015 \\
2015-2253 \text { (Homicide report) }\end{array}$ & $\begin{array}{c}\text { Johnson, } \\
\text { Brett }\end{array}$ & $\begin{array}{c}\text { Adams, } \\
\text { David }\end{array}$ & University 1 \\
\hline Jackson, & $2016-1203$ (Stalking report) & $4 / 15 / 2016$ & Carol, & $\begin{array}{c}\text { Smith, } \\
\text { Joseph }\end{array}$ & University 2 \\
Sally & $2016-1853$ (Homicide report) & $6 / 27 / 2016$ & Greg & Jonersity 3 \\
\hline Winters, & $2017-0101$ (Stalking report) & $1 / 21 / 2017$ & Jones, & Wall, & Universing \\
Carrie & $2017-0151$ (Homicide) & $11 / 9 / 2917$ & Steve & Chap & \\
\hline Hoffa, S & $2018-2875$ (Stalking \& Burglar) & $5 / 3 / 2018$ & McBride & White, J & University 4 \\
\hline
\end{tabular}

\section{Crime-Solving Process}

To foster student analytical skills, teacher participants were provided with trainings on how to navigate, comb through criminal data, analyze patterns, interview witnesses and suspects, and uncover evidence in a culminating manner. Teacher participants were randomly assigned to a group of five high school girls to facilitate the team briefing and guide the crime-solving process to find the suspects for cold cases. Each team consisted of one high school teacher and a near-peer team leader who attended prior year's academy, graduated from high school, and enrolled in college. The CF Academy were attended (F2F) in 2018, hybrid in 2019, and via Zoom in 2020 due to the COVID-19 pandemic.

A Simulated Triage Center for Handling 911 Calls. The crime solving academy started with the 911 Triage when a victim, Sarah called the police when her apartment was broken in and her laptop was stolen. Girl participants were immersed to role play as the dispatchers to handle incoming calls.

Crime Scene Investigation \& Digital Evidence. For 2018, teachers facilitated the investigation and evidence collection from a physical crime scene on UCO campus. For 2019, teachers facilitated the crime scene investigation (CSI) on campus, as well as using virtual reality to process a virtual crime scene and collect digital evidence (Figure 4). For 2020, teachers facilitated the virtual crime scene investigation and collection of evidence (e.g. blood, partial fingerprints on a murder weapon). 
FIGURE 4

VIRTUAL CRIME SCENE \& DIGITAL EVIDENCE
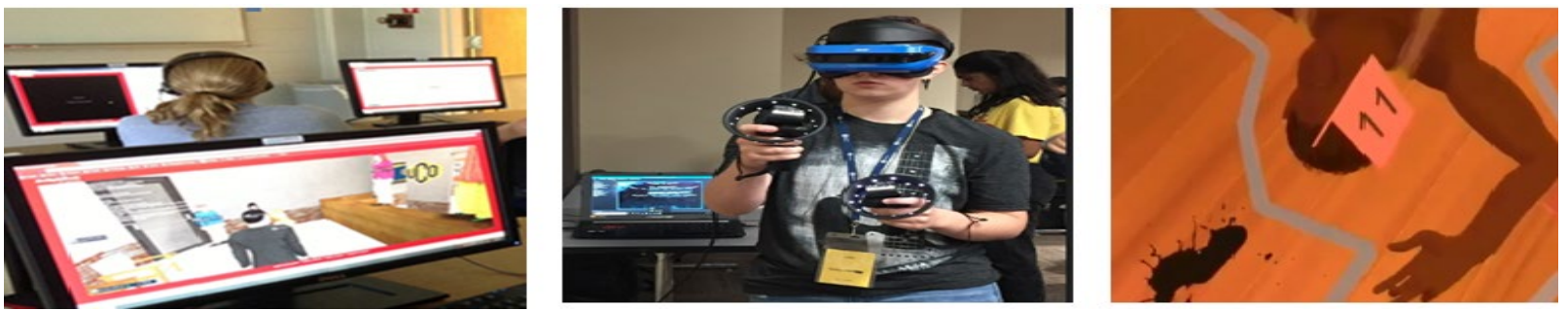

AFIS Database and Search Engine With Machine Learning. OSBI forensic scientists introduced Academy participants to AFIS, and university IS professors helped them understand how relational databases work, conceptually, and how to comb different types of data for analysis. For 2018 and 2019, teacher and student participants visited the Oklahoma State Bureau of Investigation (OSBI) and learned how to store and search fingerprints in AFIS database. For 2020, machine learning was incorporated into the design and development of a forensic search engine. Teachers facilitated the crime-solving process to help students connect the database concepts with real-world context using search engine to match the look for matching fingerprints stored in the simulated AFIS database with what's recovered from the crime scene (See Figure 5).

FIGURE 5

SIMULATED SEARCH ENGINE WITH MACHINE LEARNING

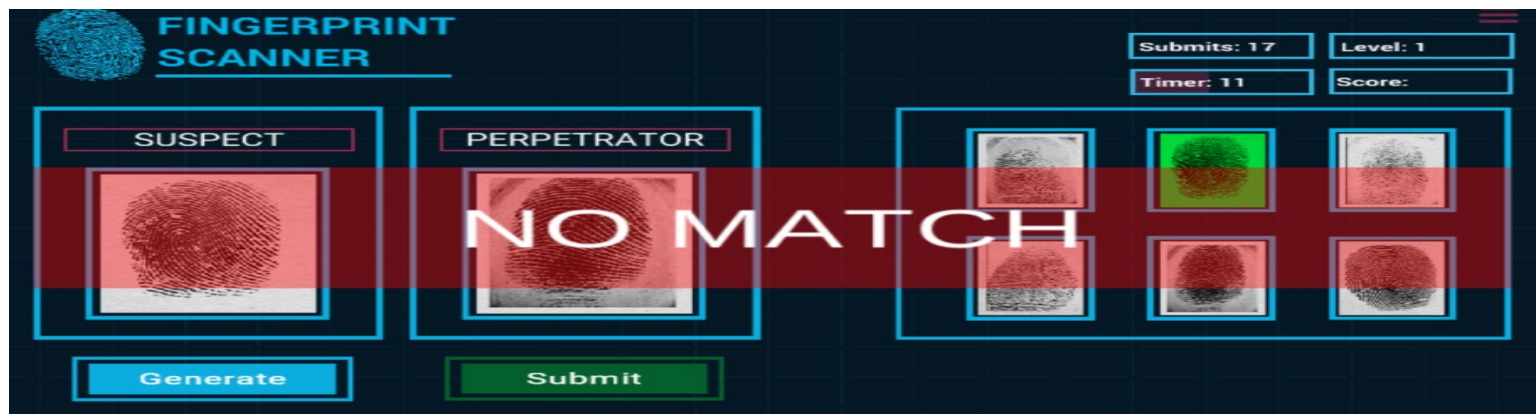

A Hybrid-Data Transfer Protocol With Blockchain Technology. Teacher participants were also exposed to another simulation designed to teaches high school girls about Blockchain - a decentralized public record system that ensures integrity in data transactions - as they played the role of crime scene investigator, securely sharing evidentiary data (See Figure 6) from field investigations with a detective and forensic artist, documenting the chain of custody to ensure admissibility of evidence.

FIGURE 6

REQUEST FOR DNA PROFILE

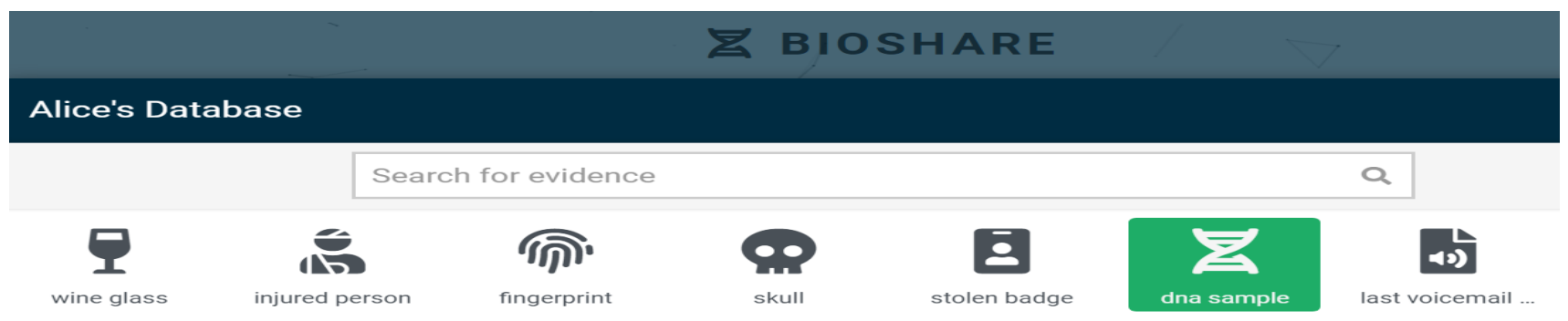


Interviews With Suspects. The Virtual detective Office is a simulated environment which was used as interview rooms for engaging girls in crime solving. Teachers facilitated this process by encouraging participants to come up with a list of critical questions to ask witnesses and suspects using the Virtual Detective Office (See Figure 7). Team leaders and girl participants were immersed and role played as investigators, witnesses, and suspects.

\section{FIGURE 7 \\ VIRTUAL INTERVIEW WITH SUSPECT VIA ZOOM}
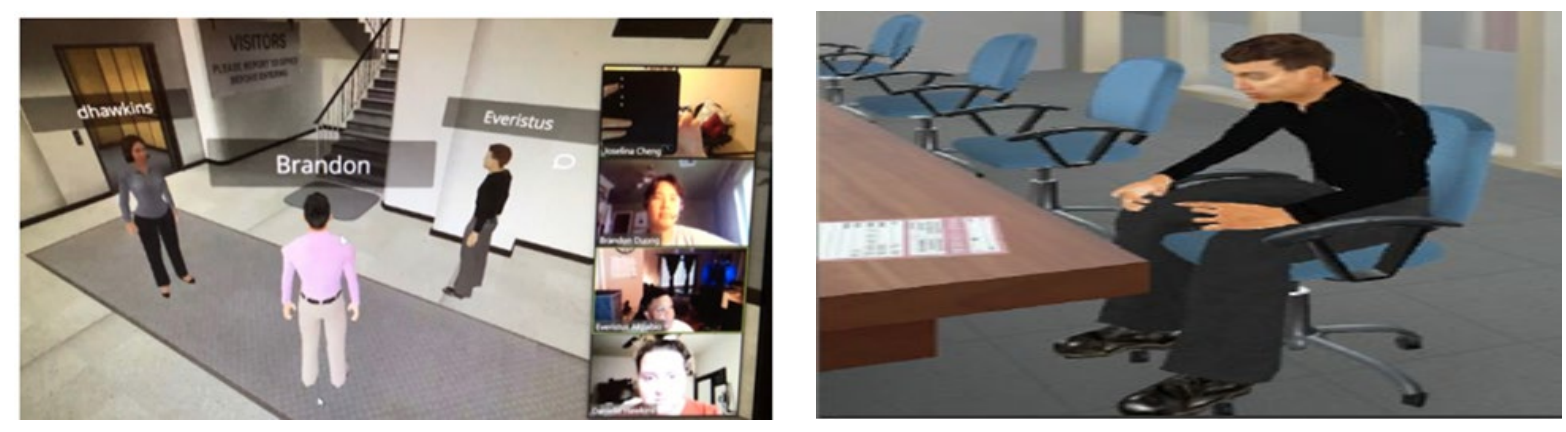

Presentation of Evidence at a Moot Court. The focus on forensics was to help learners understand the application of science to criminal and civil laws, mainly - on the criminal side - during criminal investigation, as governed by the legal standards of admissible evidence and criminal procedure (U.S. Department of Justice, n.d.; Peterson \& Sommers, 2010). Teacher participants facilitated the crime-solving process and provided guidance for the final presentations on the last day of the academy. For 2018 and 2019, girls presented their findings in person on UCO campus. For 2020, girls presented their findings virtually via Zoom.

\section{Post-Teacher Professional Development (PD)}

Teacher participants were provided with innovative toolkits (See Figure 8) to incorporate learned contents, IS, and analytics into their STEM classroom. These innovations are categorized: (1) technology (e.g. intellectual properties as discussed in sections \#2 and 3); (2) classroom tools for teaching and assessment; and (3) written content (e.g. STEM e-book, research journals, white papers, student's artifacts such as career infographics, posters for science fairs, and student-led internship projects). These innovations are available for high school teachers. On-going support is also available for teacher participants to incorporate into their STEM classrooms during the academic year.

FIGURE 8

\section{INNOVATIVE PORTFOLIO OF FORENSICS ANALYTICS TOOLKITS}

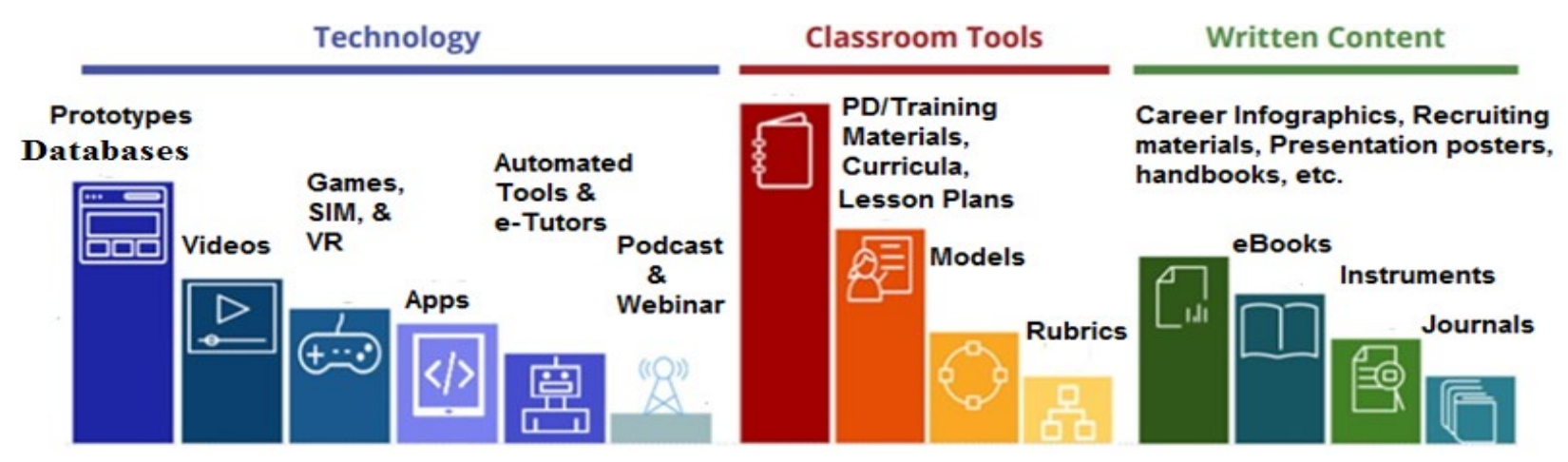




\section{METHODOLOGY}

\section{Target \& Sample Population}

The project team recruited teachers from underperforming high schools in the Central Oklahoma STEM Alliance (COSTEMA) zones (23 high school schools in 13 counties) and the Choctaw Nation (69 high schools in 11 counties and 28 communities serving 3000 students) via venues described in Section \#1 (Choctaw Nation of Oklahoma, 2020). The proposed budget was allocated to provide 30 high school teachers with PD and stipends over the 2018-2020 periods. Out of 30 teachers, who were randomly selected from a pool of applicants to participate, 20 attended the TL Conference and 14 attended the Teacher Institute and the CF Summer Academy.

\section{Instrumentation}

The project team developed the instruments to collect mixed (quantitative and qualitative) data (See Table 2). Survey instruments consisted of closed-ended questions with five-point Likert-type scales. Focus group interviews were comprised with qualitative data.

TABLE 2 INSTRUMENTS

\begin{tabular}{l|l|l|l}
\hline Instrument & When & Data Type & $\begin{array}{l}\text { Analytical } \\
\text { Method }\end{array}$ \\
\hline Pre/post-Conference Survey & TL Conference & Quantitative & Descriptive \\
\hline Pre/post-Teacher Institute survey & Teacher Institute & Quantitative & Descriptive \\
\hline Pre/post-Academy Survey & CF Summer Academy & Quantitative & Descriptive \\
\hline Teacher Focus Group & Post-Academy & Qualitative & Thematic Coding \\
\hline
\end{tabular}

\section{Data Collection}

Quantitative data were derived from the pre- and post-surveys; whereas qualitative data were derived from the focus group of teacher participants. The surveys were comprised with closed-ended questions. Teachers self-reported their awareness of emerging careers before and after attending the TL Conference, teacher institute, and the CF Summer Academy. Teachers could choose their answers from a pre-defined list of five-point, Likert-type scales: strongly disagree, disagree, undecided, agree, and strongly agree.

\section{Data Analysis}

Overall, teacher participants felt better prepared to promote STEM opportunities and share career information with girls in their classes. Of particular notes are the change in teacher career awareness, and emphasis on encouraging girls to select careers in STEM. Year three (Y3) teacher participants planned to place heavy emphasis on this goal after participating in this STEM CareerBuilder project. Below are summarized Y3 post-gain (increased percentage). Research Question (RQ) \#1: "To what degree does the TL Conference affect teacher career awareness?", cross-sector professionals representing GIU partnerships in business, government, and industry performed Ted-style talks about the trends, outlooks, and skillsets for emerging careers (e.g. data science, analytics, artificial intelligence, etc.). The pre/post differences (increases) in teacher career awareness were computed (See Table 3).

TABLE 3

THREE-YEAR COMPARISON OF TEACHER CAREER AWARENESS

\begin{tabular}{l|l|l|l}
\hline Teacher Outcome & $2018(\mathrm{~F} 2 \mathrm{~F})$ & 2019 (Hybrid) & 2020 (Virtual) \\
\hline Career Awareness & $12 \%$ & $19 \%$ & $27 \%$ \\
\hline
\end{tabular}


Research Question \#2: “To what degree does the Teacher Institute affect teacher content knowledge?", teacher cohort was enrolled in a CSI course to acquire forensic knowledge. This CSI course was developed by the National Forensic Science Technology Center, a third-party organization with specialized expertise to train forensics professionals. The knowledge increases (pre/post differences) for each year were computed (See Table 4).

TABLE 4

THREE-YEAR COMPARISON OF TEACHER CONTENT KNOWLEDGE

\begin{tabular}{l|l|l|l}
\hline Outcome (gain) & $\mathbf{2 0 1 8}($ F2F) & $\mathbf{2 0 1 9}$ (Hybrid) & $\mathbf{2 0 2 0}$ (Virtual) \\
\hline Content Knowledge & $14 \%$ & $20 \%$ & $20 \%$ \\
\hline
\end{tabular}

Research Question \#3: "To what degree does the CF Summer Academy affect teacher intention to incorporate learned forensics contents, Information systems (IS), and analytics into their own STEM classroom?", teachers were administered with the pre- and post-surveys. The gains (pre-/post score increases) of each year were computed (See Table 5).

TABLE 5 THREE-YEAR COMPARISON OF TEACHER ADOPTION INTENTION

\begin{tabular}{l|l|l|l}
\hline Survey Item Description & $\mathbf{2 0 1 8}$ & $\mathbf{2 0 1 9}$ & $\mathbf{2 0 2 0}$ \\
\hline Intention to incorporate forensic content into your STEM classroom & $50 \%$ & $67 \%$ & $75 \%$ \\
\hline Intention to incorporate IS into your STEM classroom & $33 \%$ & $45 \%$ & $66 \%$ \\
\hline Intention to incorporating analytics into your STEM classroom & $15 \%$ & $28 \%$ & $32 \%$ \\
\hline
\end{tabular}

While the intention to adopt analytics was lower when comparing to other adoption intentions, all teacher participants agreed that this STEM CareerBuilder program had positive impacts on themselves and their students. In particular, teacher participant $[\mathrm{SC}]$ applied what she learned to her two STEM classes:

- Lab \#1 Biometrics: This lab consisted hands-on activities to analyze biometrics data and perform statistical analysis. These activities were designed to foster high school students' analytical skills to better prepare them for emerging careers (e.g. Data Science).

- Lab \#2 Blood Splatter: This lab was used to set the stage for problem solving. My high school students learnt how to apply their knowledge and discover what each of those different shapes could provide insights to solve criminal cases based on what evidence was uncovered from the crime scenes.

Another high school teacher participant [JB], taught her biology classes with what she learned about the DNA. While the budget from state funded high school could not afford real DNA testing, she found a less expensive approach to engage her students in AP and Honor AP: Below are excerpts of teacher comments: "This NSF program with forensics is amazing and I love how it transforms my STEM
classroom."

"I loved that the students were able to learn about STEM and Forensics via a digital simulation and my students love learning in such contexts with real-world scenarios".

"I really enjoyed this whole experience and hope that I am able to participate again. Forensics is extremely interesting to me and I would have definitely chosen a different career path years ago if I would have been provided the information that sparked my interest at an earlier age." 
"Thank you so much for giving young women the chance to explore STEM and STEM careers!"

\section{SIGNIFICANCE, DELIMITATION, \& FUTURE STUDY}

\section{Intellectual Merit}

To address the challenge for forensic research, this paper explored new methods to investigate criminal activities and behaviors (Sachdev, Wimmer, Chen, Rebman, 2018). This paper also contributed to the intellectual merits of how teaching, learning, and working occurred during the COVID-19 pandemic provides insight on how digital platforms had transformed the K-12 educational and research landscape. These changes are likely to continue in the post-COVID19 era. Below are insights gleaned from this project through the integration of research, education, and workforce development with sustainable technologies and lasting partnerships can contribute to ITESTs' holistic workforce model to better prepare K-12 educators and young women for the highly competitive STEM workforce. Thus, findings are disseminated and shared with project stakeholders and a wider community of researchers, educators, NSF grantees, administrators, and policy makers. This project can form the basis for a scalable model to be replicated throughout the nation to further investigate how to improve STEM education, bridge skill gaps, and build an equitable, skilled, and innovative workforce for the technology-enriched society on the humantechnology frontier.

\section{Broader Impact}

This STEM Career-Builder aimed to benefit society by bridging the gender and skill gaps in order to build an equitable STEM workforce in the human-computer frontier. To ensure gender equity, the project team aimed to broaden the STEM participation by the underserved population through strategic recruitment to target women in Oklahoma where the highest representation of Native American tribes reside and fast English-speaking communities to outreach women. The project team also partnered with EPSCoR and TRiO-participating high schools, and Oklahoma Promise (a college scholarship program for low-income families) allowed the project team to address the needs of girls from low-performing schools, low-income families, and underrepresented ethnic/racial groups. Female participants were provided with careerexploration opportunities, skill-acquisition opportunities. To better prepare women with KSA needed to participate in the highly competitive STEM workforce, the project team collaborated with GIU partners, implemented virtual interventions, and developed innovative tools to help gain and acquire analytical skills. Integrating research, education, and workforce development with sustainable technologies and lasting partnerships to extend beyond the funding period to increase human capital and STEM-FA degree conferred. Findings of the program impacts on internal and external stakeholders involved directly or indirectly were disseminated via academic venues and social media to outreach the general public. This project can serve as a scalable and replicable model for researchers, educators, and grantees to further improve STEM-related education and prepare women for emerging careers on the human-computer frontier.

\section{Implications}

Administrators and educators have tremendous responsibilities to ensure that the quality of online education is pedagogically addressed when moving from traditional classroom teaching to e-teaching during the pandemic. This paper provided the frameworks of using disruptive technologies to transform STEM-related education through strategic pedagogies and simulated human-computer learning environments. The proposed STEM CareerBuilder model is pedagogically, contextually, and technologically integrated and implemented to improve the quality online education when the K-12 educational landscape was disrupted due to the pandemic. Adaptive strategies discussed in this paper can provide administrators and educators a framework to transition from the traditional brick-and-mortar classroom to virtual learning environments by enriching teaching and learning experiences with innovative technologies. 


\section{Limitation}

This study is limited by several factors. First, the sample size is too small. Second, while the grant funding period was three years, this study was limited to K-12 educators from one state (Oklahoma). The heterogeneity of the sample, the small-sample size, and geographic boundary hinder the research team to generalize the findings to the larger population ((Berenson, Levineand, and Krehbiel, 2006). Larger same size from various states is recommended.

\section{Program Calibration \& Future Study}

The low teachers' intention to incorporate analytics can be contributed due to the lack of experience with analytics. To improve teachers' intention to incorporate analytics, a workshop where teachers will be designed to provide teachers with hands-on experiences in data mining tools to analyze data, find patterns, and make predictions. The workshop can improve teacher awareness of analytics so that they will be more likely to adopt analytics. Further, to better understand what drives teachers' intention to incorporate forensic content, IS, and analytics, the survey instruments will also be revised to collect demographics for researchers to examine antecedents such as their prior knowledge, experiences, education levels. Doing so enable researchers to better understand why some teachers are more willing to adopt these new initiates when others do not. It can improve the effectiveness of PD in the long run. Moreover, different technologies of Hadoop and EnCase will also be combined in an effort to promote more effective and efficient processing of the forensic data.

\section{CONCLUSION}

COVID-19 sped up the digital transformation with emerging technologies to influence the way we teach, learn, and work. Research suggests that the post-pandemic and the future workforce will require new skills to compete against the global workforce on the computer-human frontier. Further, the current knowledge-based, global economy also demands new methods of educational delivery, knowledge acquisition, and skill development in K-12 and higher education institutions. This study contributes to the literature by providing results of an empirical investigation of the effects of the use of innovative technology on high school girls' STEM socio-emotional outcomes (e.g. career awareness and interest) and cognitive learning outcomes. As more traditional brick-and-mortar higher education institutions transition to become hybrid institutions offering online education, the knowledge of how to use innovative technology to enhance e-teaching and e-learning effectiveness becomes increasingly important. While online education can offer traditional higher education institutions an innovative and alternative educational strategy to recruit adult learners who are unable to attend traditional face-to-face classes on campus, the success of e-teaching and e-learning depends on the academic stakeholders' efforts. Without the close collaboration and participation from researchers, policymakers, administrators, faculty, and students, the cultivation of a successful elearning environment, and the delivery of quality online education can be challenging.

\section{ACKNOWLEDGMENTS}

The National Science Foundation (Award\# 1758975) funded this STEM Career-Builder project for the 2018-2021 periods to promote STEM participation by underserved high school girls. Strategies were adapted for the R\&D of multi-tiered interventions and innovative forensic analytical tools during the pandemic to continue support girls with equitable career-exploration, job-shadowing, mentoring, knowledge-acquisition, and skill-development opportunities. 


\section{REFERENCES}

Bănărescu, A. (2015). Detecting and Preventing Fraud with Data Analytics. Procedia Economics and Finance, 32, 1827-1836.

Carayannis, G., Alexander, J., \& Ioannidis, A. (2000). Leveraging knowledge, learning, and innovation in forming strategic government-university-industry (GUI) R\&D partnerships in the US, Germany, and France. Technovation, 20(9), 477-488

Catelli, A. (2016). Cyber breaches \& insider threats drive usage of forensic data analytics. Inside Counsel. Breaking News, pp. 1-3.

Choctaw Nation of Oklahoma. (2020). Student success planning. Retrieved from https://www.choctawnation.com/sites/default/files/HSSS\%20Student\%20Planner.pdf

Choo, K. (2008). Organized crime groups in cyberspace: a typology. Trends in Organized Crime, 11(3), 270-295.

Innovative Technology Experiences for Students and Teachers. (2021). Retrieved from https://www.nsf.gov/pubs/2019/nsf19583/nsf19583.pdf

Jofre, M., \& Gerlach, R.H. (2018). Fighting Accounting Fraud Through Forensic Data Analytics.

Retrieved from https://www.semanticscholar.org/paper/Fighting-Accounting-Fraud-ThroughForensic-Data-Jofre-Gerlach/6abef12dfe2ba6afae50e91e132b59e4f974fd64

Koroniotis, N., Moustafa, N., Sitnikova, E., \& Turnbull, B. (2019). Towards the development of realistic botnet dataset in the Internet of things for network forensic analytics: Bot-IoT dataset. Future Generation Computer Systems, 100, 779-796

Mortenson, M.J., Doherty, N.F., \& Robinson, S. (2015). Operational research from Taylorism to Terabytes: A research agenda for the analytics age. European Journal of Operational Research, 241(3), 583-595.

National Science Foundation. (2019). NSF's 10 Big Ideas. Retrieved from https://www.nsf.gov/news/special_reports/big_ideas/

Oklahoma Employment Security Commission, Economic Research \& Analysis Division. (n.d.). Five Oklahoma employment outlook 2016. Oklahoma City, OK.

Oklahoma State Regents of higher education. (n.d.) Retrieved from http://www.okhighered.org/

Oklahoma's 2016 STEM report card. (n.d.). Retrieved from https://www.usinnovation.org/state/pdf_cvd/ASTRA-STEM-on-Hill-Oklahoma2016.pdf

Peterson, J., \& Sommers, I. (2010). The role and impact of forensic evidence in the criminal justice process. Retrieved from https://www.ojp.gov/pdffiles1/nij/grants/231977.pdf

Sachdev, H., Wimmer, H., Chen, L., \& Rebman, C. (2018). A new framework for securing, extracting and analyzing big forensic data. The Journal of Digital Forensics, Security and Law, 13(2).

Support K-12 Computer Science Education in Oklahoma. (n.d.). Retrieved from https://code.org/advocacy/state-facts/OK.pdf

U.S Census Bureau. (n.d.). Retrieved from https://www.census.gov/library/stories/2021/01/womenmaking-gains-in-stem-occupations-but-still-underrepresented.html

U.S. Department of Justice. (n.d.). Available at U.S. Department of Defense United States Cyber Command. Cybersecurity. Retrieved from http://www.defense.gov/home/features/2010/0410_cybersec/

US Bureau of Labor Statistics. (n.d.). Retrieved from https://www.bls.gov/

Women in computer science: Getting involved in STEM. (n.d.). Retrieved from http://www.computerscience.org/resources/women-in-computer-science/ 


\section{APPENDICES}

\section{APPENDIX A AGENDA FOR THE 2020 CF SUMMER ACADEMY}

\begin{tabular}{|c|c|c|c|c|c|}
\hline \multicolumn{6}{|c|}{2020 Computer Forensics Summer Academy - Week 2} \\
\hline & Day1 & Day2 & Day3 & Day4 & Day5 \\
\hline & $7 / 20$ (Mon) & $7 / 21$ (Tue) & $7 / 22$ (Wed) & $7 / 23(\mathrm{TH})$ & $7 / 24$ (Fri) \\
\hline 8:30 AM & \multicolumn{5}{|c|}{ Team Briefing } \\
\hline Zoom Link & \multicolumn{5}{|c|}{ https://uco.zoom.us/i/92796833661?pwd=NkpMMDZQQzhObXd5aEJPcFVEVndJQT09 } \\
\hline 9:30 AM & $\begin{array}{l}\text { Welcome \& Program } \\
\text { Overview by the CF } \\
\text { Director, Dr. Cheng }\end{array}$ & $\begin{array}{c}\text { Digital Forensics - } \\
\text { by Rachel (Edmond } \\
\text { Police) }\end{array}$ & $\begin{array}{l}\text { Programming: } \\
\text { SQL (Dr. Qian) }\end{array}$ & Ruthie Kennedy - Data Mining & $\begin{array}{c}\text { Administer Post-survey; } \\
\text { Finalize presentation } \\
\text { materials }\end{array}$ \\
\hline 10:00 AM & & $\begin{array}{l}\text { CODIS database by } \\
\text { Dr. Terry Williams }\end{array}$ & $\begin{array}{l}\text { Programming: } \\
\text { Apple's Swift (K. } \\
\text { Brown) }\end{array}$ & $\begin{array}{l}\text { OK WIT Presdient - Ashley } \\
\text { Coffey }\end{array}$ & $\begin{array}{l}\text { Team presentations, digital } \\
\text { story, refelctive journaling } \\
\text { (Zoom) at Moot Court (Judge }\end{array}$ \\
\hline \multirow{2}{*}{ 11:00 AM } & \multirow{2}{*}{$\begin{array}{c}\text { Former FBI - } \\
\text { Terrorism by Dr. Bob } \\
\text { Ricks }\end{array}$} & \multirow{2}{*}{$\begin{array}{l}\text { Virtual Reality: } \\
\text { Robert Wall }\end{array}$} & \multirow{2}{*}{$\begin{array}{c}\text { Apple's Swift, } \\
\text { Blockchain/Forensi } \\
\text { cs Biometrics } \\
\text { (IBM, Everistus) }\end{array}$} & Lexi Benson & \multirow[t]{2}{*}{$\begin{array}{l}\text { Panel: Drs. R Williams, Kirk } \\
\text { Knestis, Lexi Benson, \& } \\
\text { Ashley Coffey) }\end{array}$} \\
\hline & & & & $\begin{array}{l}\text { Virtual Interviews with Suspects } \\
\text { (Simulation) }\end{array}$ & \\
\hline $12-1 \mathrm{pm}$ & \multicolumn{4}{|c|}{ Lunch time on your own \& check in with team teacher } & \multirow{3}{*}{ Adjourn } \\
\hline 1:00 PM & $\begin{array}{c}911 \text { Call; OSBI; Case } \\
\text { summary; DNA by Dr. } \\
\text { Rhonda Williams }\end{array}$ & $\begin{array}{l}\text { OSBI: Fingerprints } \\
\text { \& blood testing }\end{array}$ & $\begin{array}{l}\text { Virtual Interviews } \\
\text { with witness } \\
\text { (Simulation) }\end{array}$ & $\begin{array}{l}\text { Virtual Interviews with Suspects } \\
\text { (Simulation) }\end{array}$ & \\
\hline $2 p m-5 p m$ & \multicolumn{4}{|c|}{$\begin{array}{l}\text { Team activities: Solve cold cases \& submit reports to Google Docs; } \\
\text { Team } 1=\text { https://drive.google.com/drive/folders/1mH1dgF2eEzq6HE2bvUqxSXoT2ne0O6Cs?usp=sharing); } \\
\text { Team 2=https://drive.google.com/drive/folders/1JdCZdEqggsSWWWWcFILW5xov6IUdS8ID?usp=sharing }\end{array}$} & \\
\hline
\end{tabular}

\section{APPENDIX B}

\section{EXCERPTS OF COLD CASES GENERATED FROM A RELATIONAL QUERY}

\begin{tabular}{|c|c|c|c|c|c|c|}
\hline $\begin{array}{l}\text { Victim or } \\
\text { Witness }\end{array}$ & Cold Case \# & Report Date & $\begin{array}{l}\text { Reporting } \\
\text { Officer }\end{array}$ & Detective & State & $\begin{array}{l}\text { College } \\
\text { Campus }\end{array}$ \\
\hline $\begin{array}{l}\text { Williams, } \\
\text { Jessica }\end{array}$ & $\begin{array}{l}\text { 2015-1789 (Stalking report) } \\
\text { 2015-2253 (Homicide report) }\end{array}$ & $\begin{array}{l}10 / 18 / 2015 \\
12 / 30 / 2015\end{array}$ & $\begin{array}{l}\text { Johnson, } \\
\text { Brett }\end{array}$ & $\begin{array}{l}\text { Adams, } \\
\text { David }\end{array}$ & OK & $\mathrm{OU}$ \\
\hline $\begin{array}{l}\text { Jackson, } \\
\text { Sally }\end{array}$ & $\begin{array}{l}\text { 2016-1203 (Stalking report) } \\
\text { 2016-1853 (Homicide report) }\end{array}$ & $\begin{array}{l}4 / 15 / 2016 \\
6 / 27 / 2016 \\
\end{array}$ & $\begin{array}{l}\text { Caroll, } \\
\text { Greg }\end{array}$ & $\begin{array}{l}\text { Smith, } \\
\text { Joseph }\end{array}$ & TX & TUD \\
\hline $\begin{array}{l}\text { Winters, } \\
\text { Carrie }\end{array}$ & $\begin{array}{l}\text { 2017-0101 (Stalking report) } \\
\text { 2017-0151 (Homicide) }\end{array}$ & $\begin{array}{l}1 / 21 / 2017 \\
11 / 9 / 2917\end{array}$ & $\begin{array}{l}\text { Jones, } \\
\text { Steve }\end{array}$ & $\begin{array}{l}\text { Wall, } \\
\text { Chap }\end{array}$ & $\mathrm{OK}$ & OSU \\
\hline $\begin{array}{l}\text { Hoffa, } \\
\text { Sarah }\end{array}$ & 2018-2875 (Stalking \& Burglar) & $5 / 3 / 2018$ & $\begin{array}{l}\text { McBride, } \\
\text { Andrew }\end{array}$ & $\begin{array}{l}\text { Not } \\
\text { assigned }\end{array}$ & $\mathrm{OK}$ & $\mathrm{UCO}$ \\
\hline
\end{tabular}

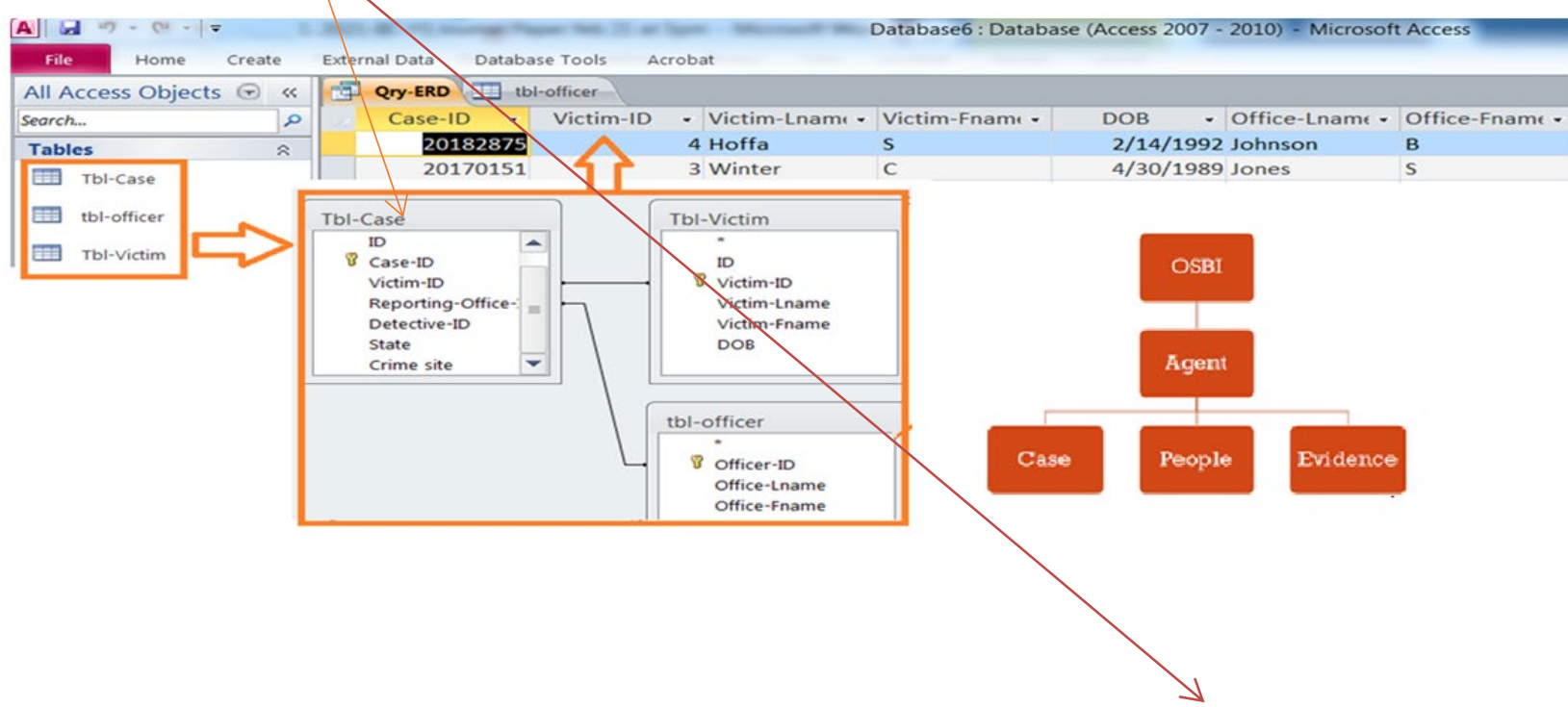

Journal of Higher Education Theory and Practice Vol. 21(8) 2021129 
A Crime/Incident Report

Computer Forensics Summer Academy (Not a Real Report)

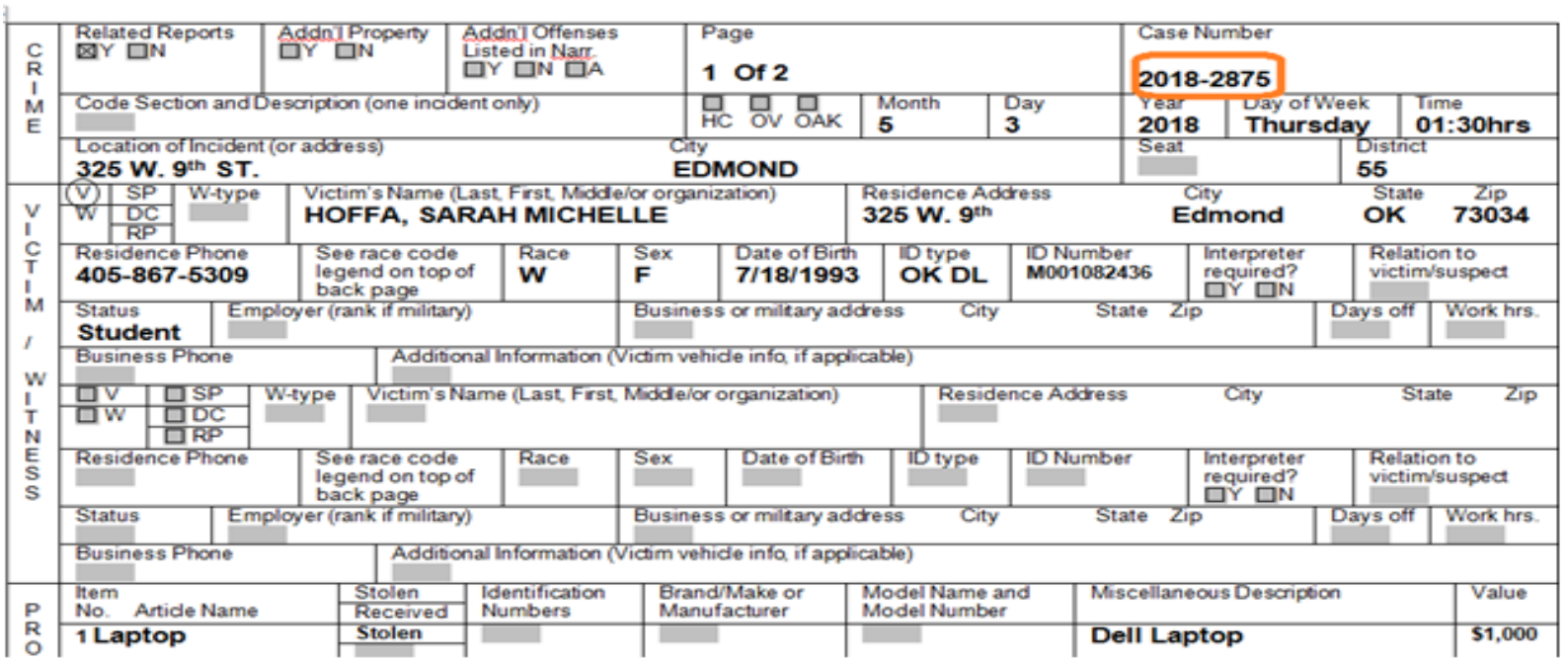

130 Journal of Higher Education Theory and Practice Vol. 21(8) 2021 